\title{
Manajemen Administrasi Sekolah dalam Meningkatkan Mutu Pendidikan di Indonesia
}

\author{
Hilman Yusri \\ Program Studi Pendidikan IPA Fakultas Matematika dan Ilmu Pengetahuan Alam Universitas Negeri \\ Padang \\ hilmanyusri79@gmail.com
}

\begin{abstract}
ABSTRAK
Sumber daya manusia Indonesia perlu ditingkatkan melalui Pendidikan. Pendidikan Indonesia saat ini masih memprihatinkan. Penyebab lemahnya pendidikan di Indonesia dapat diamati pada output pendidikan dengan efektivitas dan efisiensi yang belum maksimal. Upaya pemerintah dalam mengatasi hal ini harus perlu diperhatikan dengan serius. Untuk mewujudkan efektivitas dan efisiensi pendidikan dalam mencapai tujuan sesuai yang diinginkan, perlu ditata dan disusun proses dari pendidikan dengan manajemen administrasi sekolah yang akan membantu serta menunjang pendidikan sehingga memudahkan dalam meningkatkan mutu pendidikan di Indonesia.
\end{abstract}

Kata kunci: manajemen, administrasi, pendidikan

\begin{abstract}
Indonesia's human resources need to be improved through education. Current Indonesian education is still a concern. The cause of weak education in Indonesia can be observed in educational output with effectiveness and efficiency that has not been maximized. Government efforts in overcoming this must be taken seriously. To realize the effectiveness and efficiency of education in achieving the goals as desired, it is necessary to organize and compile the process of education with school administration management that will help and support education so as to facilitate in improving the quality of education in Indonesia.
\end{abstract}

Keywords: management, administration, education

\section{LATAR BELAKANG}

Indonesia merupakan negara yang memiliki penduduk dan angka kelahiran dengan kategori relatif tinggi. Dengan keadaan tersebut, tentunya diharapkan sebanding dengan kualitas sumber daya manusia terutama di kalangan generasi muda yang nantinya akan menjadi penerus bangsa. Kemajuan teknologi pada era 4.0 sekarang menuntut kita untuk lebih dapat bersaing dengan negara lain dengan modal sumber daya manusia yang berkualitas. Salah aspek yang berperan penting dalam meningkatkan sumber daya manusia tersebut adalah pendidikan.

Pendidikan merupakan suatu indikator suatu negara yang menunjukkan bahwa negara tersebut sudah maju. Pendidikan yang berkualitas tentunya akan melahirkan generasi yang cemerlang, baik itu dari segi daya saing maupun kompentensi di berbagai bidang ilmu. Sehingga meningkatkan mutu pendidikan dari suatu ke generasi berikutnya.
Melihat kualitas pendidikan di Indonesia saat ini diperlukan perhatian khusus. Karena dari data (Ali, 2018) pada tahun 2018, Indonesia memiliki skor 0,603 atau berada di posisi peringkat 108 di dunia $^{[1]}$.

Penyebab rendahnya kualitas pendidikan di Indonesia disebabkan karena permasalahan efisiensi dan efektivitas proses pendidikan yang sampai sekarang belum dapat dituntaskan dengan baik. Hal ini ditandai dengan masih lemahnya kesadaran generasi muda akan pentingnya menuntut ilmu (bukan sekedar mendapat nilai yang bagus), fasilitas sekolah yang belum memadai, rendahnya relevansi tujuan pendidikan dengan kebutuhan di lapangan dan pendidik masih kurang memperhatikan pentingnya mutu pendidikan.

Beberapa upaya pemerintah dalam bidang pendidikan adalah dengan mengembangkan kurikulum, program perpustakaan, bantuan operasional siswa (BOS), dan sebagainya. Namun hasilnya belum memuaskan secara merata karena contohnya saja kurikulum 
disusun oleh pemerintah pusat sedangkan kebijakan tersebut belum tentu bisa diterapkan di semua daerah, terutama di daerah terpencil.

Untuk terwujudnya efektivitas dan efisiensi pendidikan dalam mencapai tujuan sesuai dengan yang diharapkan perlu diperhatikan penataan administrasi serta manajemen dalam pendidikan. Sebagaimana yang disebutkan oleh (A. Rahani, 1991) dalam buku Pedoman Penyelenggaraan Administrasi Pendidikan Sekolah bahwa tujuan pokok dari administrasi atau manajemen pendidikan adalah untuk memanifestasikan efektivitas, efisiensi dan juga produktivitas dalam proses operasional pendidikan guna mencapai tujuan pendidikan di lingkungan pendidikan formal (sekolah) yang optimal. ${ }^{[2]}$

Berdasarkan uraian diatas, penulis tertarik membahas Manajemen Administrasi Sekolah sebagai salah satu solusi dalam meningkatkan mutu pendidikan.

\section{PEMBAHASAN}

\section{A. Pengelolaan Peserta Didik}

Tujuan manajemen peserta didik adalah agar teraturnya setiap kegiatan kesiswaan dan agar proses pembelajaran di sekolah berjalan dengan lancar. Menurut pendapat beberapa ahli, tujuan manajemen peserta didik yaitu menciptakan kondisi lingkungan sekolah yang baik serta menciptakan kodisi belajar yang tertib sehingga tercapai tujuan pendidikan yang efektif serta efisien.

Menurut (Bustari, 2005) tugas utama dalam manajemen peserta didik yaitu penerimaan peserta didik baru, kegiatan proses belajar mengajar serta bimbingan dan pembinaan disiplin.

\section{B. Pengelolaan Pendidik dan Tenaga Kependidikan}

Administrasi pendidik dan tenaga kependidikan meliputi Pendayagunaan Ketenagaan, Daftar Penilaian Pelaksanaan Pekerjaan (DP3), Daftar Urut Kepangkatan (DUK), Mutasi Kepangkatan, Pengembangan Ketenagaan, Usaha Kesejahteraan Pegawai, dan Tata Tertib kerja.
Berdasarkan PPRI No. 19 Tahun 2005 tentang Standar Nasional Pendidikan, Pasal ayat 7 bahwa standar pendidik dan tenaga kependidikan merupakan kriteria pendidikan prajabatan dan kelayakan fisik maupun mental, serta pendidikan dalam jabatan. Adapun, administrasi standar pendidik dan tenaga kependidikan meliputi kualifikasi akademik dan kompetensi dari pendidik dan tenaga kependidikan.

Menurut (Sabandi, 2013) tinggi rendahnya prestasi belajar tersebut memiliki kaitan yang erat dengan kemampuan guru dalam pengelolaan belajar. Guru hendaknya juga mempunyai kepribadian yang jujur, berakhlak serta berbudi luhur, berwibawa, beriman, berwawasan luas dan lain-lain. Selain itu juga dibutuhkan guru yang kreatif dan terbuka terhadap perkembangan kemajuan siswa.

\section{Pengelolaan Kurikulum dan Proses Pembelajaran}

Kurikulum merupakan aspek yang paling berpengaruh dalam keberhasilan pendidikan. Kurikulum merupakan sebuah sistem dari program pembelajaran untuk mencapai tujuan pembelajaran, sehingga kurikulum berperan penting dalam mewujudkan sekolah yang bermutu atau berkualitas. Pembaruan kurikulum merupakan upaya untuk mengembangkan pendidikan sesuai dengan zamannya dan kebutuhan pendidikan itu sendiri.

Kurikulum sekarang ini dikembangkan oleh pemerintah pusat. Namun kebijakan kurikulum ini belum merata karena terdapat kendala di beberapa daerah terutama daerah yang terpencil. Solusinya agar pemerintah dapat membangun fasilitas baik itu sarana dan prasarana secara masif dan rata terutama di daerah terpencil agar dapat memperkecil permasalahan ataupun kendala yang terjadi serta supervisi guru lebih digencarkan untuk meningkatkan kualitas pendidikan yang tertinggal.

Untuk proses pembelajaran terdiri dari perencanaan, pelaksanaan, penilaian dan pengawasan pembelajaran. Disusun sedemikian rupa agar proses pembelajaran dapat berjalan dengan efektif dan efisien sesuai tujuan yang diharapkan. 


\section{Pengelolaan Sarana dan Prasarana}

Dalam menunjang proses pembelajaran tentunya memerlukan sarana dan prasarana. Baik itu media sebagai fasilitas yang membantu dalam pemahaman belajar. Maupun gedung yang memadai sebagai tempat belajar supaya kegiatan belajar mengajar bisa berjalan lancar dan aman.

Menurut Kepmendikbud No. 053/U/2001 tentang Standar Pelayanan Minimal (SPm), ada persyaratan minimal untuk sekolah dalam menyelanggarakan pendidikan agar bisa dikatakan fasilitas sekolah tersebut sudah cukup atau lengkap seperti luas lahan, perabot/fasilitas kelas yang lengkap, peralatan/laboratorium/media sebagai sarana belajar, infrastruktur yang menunjang, sarana olahraga, dan lain-lain. Aturan itu sangat tepat dan perlu diperhatikan supaya fasilitas setiap sekolah sudah bisa merata dan tidak ada yang tertinggal walaupun berada di daerah terpencil.

\section{E. Pengelolaan Anggaran/Biaya}

Terdiri dari 2 dimensi, yaitu dimensi pemasukan biaya/sumber dana dan pengeluaran biaya sekolah/alokasi dana. (Wijono, 1989)

Sumber biaya dapat berasal dari pemerintah, iuran sekolah maupun sumbangan dari masyarakat. Sedangkan alokasi dana disalukan kepada pengeluaran modal dan pembangunan sekolah.

Tenaga yang mengelola anggaran itu tentu merupakan orang yang mengerti dengan akutansi keuangan sehingga pengelolaan dapat berjalan lancar serta dapat meminimalisir kesalahan yang dapat terjadi.

\section{F. Pengelolaan Tata Usaha}

Tata usaha sangat berperan penting di bidang administrasi yang bertanggung jawab terhadap segala pelayanan administrasi dan operasional di suatu sekolah.

Adapun tugas tata usaha secara umum adalah pengelolaan surat dan arsip.

\section{G. Pengelolaan Organisasi}

Demi kelancaran operasional, tentunya dibutuhkan pengelolaan organisasi yang baik.
Karena setiap komponen organisasi saling menunjang pendidikan sesuai perannya dan saling diperlukan koordinasi yang baik tentunya.

\section{H. Pengelolaan Hubungan Sekolah dengan Masyarakat (HUMAS)}

Humas bertanggung jawab menjalin komunikasi dengan masyarakat yang ada di sekitar lingkungan sekolah.

Dengan adanya komunikasi yang baik antar sekolah dan masyarakat dapat menjalin hubungan yang timbal balik sehingga dapat saling memberi manfaat.

Salah satu wujud hubungan sekolah dengan masyarakat yaitu mengundang komite atau orang tua/wali murid untuk membantu pemecahan masalah yang ada di sekolah.

\section{Pengelolaan Bimbingan Konseling}

Siswa membutuhkan bimbingan dan arahan dari guru mengarahkan untuk pengambangan kemampuan yang dimiliki siswa agar bisa lebih menjadi pribadi yang dewasa dan mandiri.

Bimbingan dapat berupa pengembangan kemampuan siswa, pemberian informasi, pemberian bimbingan secara berkelompok, serta memberikan pandangan kepada siswa.

\section{Penutup}

Manajemen Administrasi Sekolah merupakan hal yang penting dalam menunjang pendidikan sehingga membantu meningkatkan daya mutu pendidikan.

Manajemen administrasi dapat berupa pengelolaan peserta didik, pengelolaan pendidik dan tenaga kependidikan, pengelolaan kurikulum dan proses pembelajaran, pengelolaan sarana dan prasarana, pengelolaan anggaran/biaya, pengelolaan tata usaha, pengelolaan organisasi, pengelolaan humas serta pengelolaan bimbingan konseling. Semua pengelolaan ini bukan lain bertujuan untuk menciptakan pendidikan yang efektif dan efisien dalam mencapai tujuan. 


\section{DAFTAR PUSTAKA}

A. Rahani, H. A. A. (1991). Pedoman Penyelenggaraan Administrasi Pendidikan Sekolah. Jakarta: BUMI AKSARA.

Ali, M. N. (2018). Peringkat Pendidikan Indonesia dan Budaya Buruknya. Retrieved April 22, 2019, from https://siedoo.com/berita-4965peringkat-pendidikan-indonesia-dan-budayaburuknya/

Bustari, M. (2005). Manajemen Peserta Didik. Yogyakarta: FIP UNY.

Sabandi, A. (2013). Supervisi Pendidikan Untuk Pengembangan Profesionalitas Guru Berkelanjutan. Jurnal Ilmiah Ilmu Pendidikan, XIII(2), 1-9.

Wijono. (1989). Administrasi dan Supervisi Pendidikan. Retrieved from http://repository.uin-suska.ac.id/10370/1/Adm dan Supervisi Pendidikan.pdf 